Research Centre (BRC) award to Guy's and St. Thomas' NHS Foundation Trust in partnership with King's College London and King's College Hospital NHS Foundation Trust.

Disclosure of interest K. Steel: None declared, S.-Y. Wu: None declared, U. Srenathan: None declared, E. Chan: None declared, B. Kirkham Grant/research support from: Novartis, L. Taams Grant/research support from: Novartis/UCB

\section{IL-7 IN PRIMARY SJÖGREN SYNDROME (PSS) IS SECRETED BY SALIVARY GLAND EPITHELIAL CELLS AFTER IFN STIMULATION AND IS ASSOCIATED WITH B- CELL ACTIVATION}

${ }^{1} \mathrm{~A}$ Virone, ${ }^{1} \mathrm{~J}$ Pascaud, ${ }^{1} \mathrm{E}$ Riviere, ${ }^{2} \mathrm{~J}-\mathrm{E}$ Gottenberg, ${ }^{3} \mathrm{~V}$ Le Guern, ${ }^{4} \mathrm{X}$ Mariette, ${ }^{4} \mathrm{G}$ Nocturne* ${ }^{1}$ INSERM, Le Kremlin Bicetre; ${ }^{2}$ Université de Strasbourg, Strasbourg; ${ }^{3}$ APHP Hop Cochin, Paris; ${ }^{4}$ Université Paris Sud, Le Kremlin Bicetre, France

\subsection{6/annrheumdis-2018-EWRR2018.17}

Introduction pSS is characterised by a strong IFN signature, ectopic germinal centres formation and a chronic blood lymphopenia. IL-7 plays a central part in T cells homeostasis and in lymphoid structures organisation.

Objectives To assess the role of IL-7 in pSS pathogenesis.

Methods IL-7 serum level was assessed in 372 pSS patients and 73 paired controls. Primary cultures of salivary gland epithelial cells (SGEC) from patients and controls were stimulated by Poly I:C $30 \mathrm{ng} / \mathrm{ml}$, IFN- $\alpha 600 \mathrm{UI} / \mathrm{ml}$, IFN- $\gamma 5 \mathrm{ng} / \mathrm{ml}$ and IFN- $\lambda$ (IL-28) $25 \mathrm{ng} / \mathrm{ml}$ for 72 hours. IL-7 secretion was tested in culture supernatant by ELISA. IL-7 expression after 24 hours stimulation was assessed by quantitative RT-PCR. IL7 and its receptor's expressions were evaluated in RNA-Seq analysis from cells form salivary glands biopsies (SGB) and PBMC.

Results pSS patients had higher serum IL-7 levels than controls: $7.56 \mathrm{ng} / \mathrm{ml} \pm 8.52 \quad$ (mean $\pm \mathrm{SD}$ ) versus $4.86 \mathrm{ng} / \mathrm{ml} \pm 5.59$; $\mathrm{p}<0.0001$. A positive correlation with $\mathrm{B}$ cells activation markers, IFN-induced chemokines and disease activity markers was observed. In multivariate analysis, serum IL-7 level was associated with CXCL13, anti-SSA, RF, $\kappa$ light-chain and low C4.

SGEC stimulation with Poly I:C, IFN- $\alpha,-\gamma$ and $-\lambda$ induced IL-7 protein secretion in the supernatant $(p=0.002, p=0.004$, $\mathrm{p}=0.007, \mathrm{p}=0.004$ respectively). A trend for a greater IL-7 production in pSS patients compared to controls was observed. IL-7 expression was confirmed by quantitative RTPCR. Among cell subsets purified ex vivo from SGB and PBMC, RNA-Seq analysis showed a greater expression of IL-7 by epithelial cells of patients compared to controls $(p=0.03)$. No difference was observed regarding $\mathrm{T}$ and $\mathrm{B}$ cells either from biopsies or PBMC. IL-7 receptor expression was equivalent between patients and controls. Analysis of T cells exhaustion profile and IL-7 intracellular signalling are on-going.

Conclusions Our data demonstrate that IL-7 is secreted within the target tissue of pSS by SGEC after stimulation by IFNs. This IFN/IL-7 pathway can be involved in the organisation of ectopic germinal centres found in pSS. But more importantly, since Il-7 is one of the major controller of homeostasis of $\mathrm{T}$ cells, this IFN/IL-7 pathway could be involved in the persistent lymphopenia which is a hallmark of the disease, either by favouring exhaustion of $\mathrm{T}$ cells or by an impaired function of the IL-7 intracellular signalling. Both mechanisms are currently explored and will be presented.

Disclosure of interest None declared

\section{CCR6+ T HELPER CELLS DRIVE ANTIGEN-INDUCED ARTHRITIS VIA THE IL-23R PATHWAY}

${ }^{1}$ W Razawy*, ${ }^{1}$ PS Asmawidjaja, ${ }^{1} \mathrm{~A}-\mathrm{M}$ Mus, ${ }^{1} \mathrm{~N}$ Salioska, ${ }^{2} \mathrm{M}$ Van Meurs, ${ }^{2} \mathrm{H}$ HaspelsBrouwers, ${ }^{3} \mathrm{~N}$ Kops, ${ }^{1} \mathrm{E}$ Lubberts, on behalf of Rheumatology. ${ }^{1}$ Rheumatology; ${ }^{2}$ Immunology; ${ }^{3}$ Orthopedics, Erasmus Medical Centre, Rotterdam, Netherlands

\subsection{6/annrheumdis-2018-EWRR2018.18}

Introduction The IL-23/IL-17A immune pathway is important for the progression of $\mathrm{T}$ cell-mediated arthritis. However, it is not known where IL-23R $\mathrm{R}^{+} \mathrm{T}$ cells locate at different stages of arthritis and which IL-23R ${ }^{+}$cells are drivers of joint inflammation.

Objectives We aimed to identify IL-23R ${ }^{+} \mathrm{T}$ cells in the secondary lymphoid organs and synovium during the development and progression of antigen-induced arthritis (AIA). Furthermore, we studied which IL-23R ${ }^{+}$cells drive full-blown AIA. Methods To induce AIA, IL-23R $\mathrm{R}^{+/+}$(wild type), heterozygous IL-23R ${ }^{+/ G F P}$ (IL-23R-GFP.KI reporter), and IL-23R ${ }^{\text {GFP/GFP }}$ (IL23RKO) mice were immunised with methylated bovine serum albumin (mBSA) in Complete Freund's Adjuvant. After 7 days mice were injected in the knee joints with mBSA. Mice were macroscopically scored and knees were used for histological analysis of inflammation and bone erosion. The spleen, inguinal and popliteal lymph nodes, and the synovium were collected and assessed for expression of GFP/IL-23R ${ }^{+}$cells. Adoptive transfer of $\mathrm{CCR}^{+} \mathrm{T}$ helper cells and $\gamma \delta \mathrm{T}$ cells from heterozygous mice into IL-23RKO mice was performed via i.v. injection prior to AIA induction.

Results AIA disease progression was mainly driven by the IL23R pathway as IL-23RKO mice had significantly lower arthritis scores and less bone damage. Heterozygous mice had similar disease scores to WT mice, indicating that half of the receptor expression is sufficient to drive disease. Flow cytometric analysis of GFP/IL-23R expression revealed that among the $\mathrm{T}$ cells, CCR6 ${ }^{+} \mathrm{T}$ helper and $\gamma \delta \mathrm{T}$ cells but not $\mathrm{CD}^{+} \mathrm{T}$ cells expressed the IL-23R in the lymphoid tissues. During the progressive phase of arthritis, lymphoid tissue cell numbers were lower in IL-23RKO mice. On the other hand, the overall percentage of $\mathrm{T}$ cells was higher in the IL-23RKO lymphoid tissues, suggesting that these cells develop but remain in the lymphoid tissues. $\mathrm{CD}^{+}$and $\gamma \delta \mathrm{T}$ cells but not $\mathrm{CD}^{+} \mathrm{T}$ cells were abundantly present in the WT joints during arthritis, but decreased in IL-23RKO joints. Adoptive transfer of CCR6 ${ }^{+} \mathrm{T}$ helper and $\gamma \delta \mathrm{T}$ cells into IL-23RKO mice revealed that $\mathrm{CCR}^{+} \mathrm{T}$ helper cells are the main drivers of AIA.

Conclusions AIA progression is driven by IL-23R signalling and CCR6 + T helper cells can rescue arthritis in IL-23R deficient mice. Among the T cells, only $\mathrm{CCR}^{+} \mathrm{T}$ helper and $\gamma \delta$ $\mathrm{T}$ cells express the IL-23R in the lymphoid tissues. IL23R signalling might be involved in $\mathrm{T}$ cell proliferation and/or migration, since $\mathrm{CD}^{+}$and $\gamma \delta \mathrm{T}$ cell infiltration is decreased in the IL-23RKO synovium.

Disclosure of interest None declared 